\title{
ESTRATEGIAS ICÓNICAS EN LAS COMEDIAS MITOLÓGICAS DE CALDERÓN
}

\author{
Enrica Cancelliere \\ Dipartimento di Studi Umanistici \\ Facoltà di Lettere e Filosofia \\ Università degli Studi di Palermo \\ Viale delle Science, Edificio 12 \\ 90128 Palermo. Italia \\ enricacancelliere@libero.it
}

El análisis que voy a presentar se basa en el corpus de las «comedias mitológicas» propias de las fiestas palaciegas, considerando la mitología el campo privilegiado de la construcción poética y artística del «deber ser» metafórico, y, con respecto al teatro de corte, el nivel más alto de síntesis de las artes — poesía, artes figurativas, escenografía, música-.

Intentaremos enfocar, pues, la atención no en analogías de tipo temático sino en el procedimiento metodológico según el cual, la interrelación entre pintura y poesía, elabora una representación ad oculos del «deber ser» como fundamento de la creación poética ${ }^{1}$.

A este propósito Aristóteles en la Poética cita la imagen de Píndaro de la "cierva de los cuernos de oro» ${ }^{2}$. Lo que la realidad empírica nos da como imposible puede hacerse necesario en la imaginación poética: la cierva de Artémides, imagen que representa el doble de la misma diosa, por ese motivo debe necesariamente tener cuernos de oro; y esto no causará sorpresa

\footnotetext{
${ }^{1}$ Ver Arellano, 1995, pp. 411-442.

${ }^{2}$ Aristóteles, Poética, pp. 227-228, vv. 1460b-30.
} 
porque lo que aparece incongruente en la realidad empírica resulta más verdadero que lo verdadero en la imagen poética construida por el ingenio.

En la diégesis de la poesía dramática o épica, el «deber ser» se hace imprescindible con respecto a la acción que va desarrollándose según una manera necesaria. El plot en su conjunto se construye como imagen mental, como síntesis figurativa que incluye en su articulación significante todas las representaciones de imágenes necesarias y sus correlaciones, incluso las más conflictivas, al fin de representarnos a la mente el ineluctable desarrollo de un acontecimiento que, en consecuencia, se construye según un procedimiento racional, por tanto como procedimiento de tipo cognitivo.

La ejemplaridad racionalizante de la elaboración metafórica permite llegar a la explicación del misterio de la naturaleza y del cosmos demostrando el valor universal del principio de formatividad que gobierna todo el universo y que se manifiesta en el «deber ser» artístico. Este principio se con-

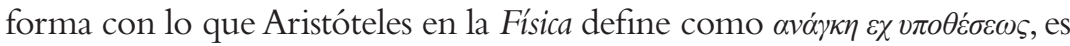
decir lo que es necesario gracias a una determinada condición. El principio de la formatividad hace posible en la poesía la representación de acciones perversas y crímenes hasta los más horrendos por el hecho de que ponen en marcha un procedimiento catártico en el espectador.

En el desarrollo del drama — según el étimo del verbo dórico $\delta \rho \alpha-$ los personajes actúan suscitando ad oculos la acción, por lo cual la imagen mental activada por la metáfora se hace imagen concreta. Lo que percibimos con la mente y lo que vemos como representación del «deber ser» - escena o representación figurativa- constituye un patrimonio de memoria que a su vez produce nuestros $\varphi \alpha v \tau \alpha ́ \sigma \mu \alpha \tau \alpha$, término que Aristóteles usa para indicar las representaciones mentales, de objetos singulares concretos, activadas por la «fantasía» y elaboradas a través de la reminiscencia.

Y puesto que estos resultados se manifiestan sólo en la realidad poética, y no en la realidad empírica y contingente, consigue con esto que la imagen mental del «deber ser» remite siempre a una otredad a través de una producción de imágenes del todo alejada de la realidad y del concepto inicial, como exhibición de la fantasía , es decir metáfora: traslación de un término ausente a una imagen, presente a la mente o a los ojos, que interpreta aquel término según relaciones de connotación. La "cierva de los cuernos de oro» es pues metáfora, y la poesía un desarrollo e interrelación de metáforas. Éstas, cargadas de evéçcla, se ofrecen a la vista de la mente con una fuerza de visualización. 
De ahí la importancia que, en las estéticas manieristas y barrocas,

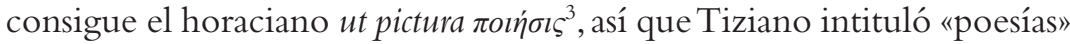
sus pinturas mitológicas, encargadas por Felipe II, concretas visiones metafóricas como traducción de metáforas poéticas.

Se basa, pues, en sólidos fundamentos teóricos la atención de Calderón en sus comedias mitológicas ${ }^{4}$ a las "poesías» de Tiziano y, por supuesto, la atención a otras obras maestras de la pintura probablemente conocidas a través de las reproducciones de «múltiplos», que, como es sabido, circulaban en España y en particular en la Corte.

La mitología constituye el campo privilegiado porque representa no el mundo empírico sino el de lo imaginario a partir del cual puede realizarse el principio del «deber ser» como metáfora que se hace concreta gracias al valor simbólico adquirido por las imágenes desde la Antigüedad hasta la edad moderna.

Las Eıкóves de Filostrato, la teoría de los simulacros de Porfirio, los tratados de Iconología renacentistas han formulado aquellas análisis, basadas en la relación entre mundo mitológico, imágenes y metáforas, que concretamente han atravesado la historia del arte y de la poesía occidentales. A partir de estos tratados en nuestra época se han desarrollado los estudios de iconología de Warburg, Panofsky y otros iconólogos los cuales han analizado la relación inseparable entre las artes, sus técnicas y creación artística, poniendo de relieve el hecho de que la literatura funciona como didascalia interpretativa activando, además, la elaboración de los $\varphi \alpha v \tau \alpha \dot{\sigma} \mu \alpha \tau \alpha$; relación, por supuesto, reversible en el sentido de que incluso las artes figurativas pueden funcionar como didascalia del texto poético.

Según había teorizado Francisco Pacheco en su Arte de la Pintura, Calderón considera la pintura como paradigma de todas las artes, como demuestra en El informe sobre la pintura ${ }^{5}$, porque su arte consiste en el proporcionar a las ideas la forma y el volumen de figuras aparentes, usando un lenguaje mudo que utiliza específicos elementos visivos y específicas técnicas ${ }^{6}$, según afirmaba Francisco de Holanda en su De Pintura Antigua .

\footnotetext{
${ }^{3}$ Ver Lee, 1982; ver Sorolla, 1988.

${ }^{4}$ Ver Chapman, 1954, pp. 35-67.

${ }^{5}$ Ver Curtius, 1936.

${ }^{6}$ Ver Cancelliere, 1981.

${ }^{7}$ Francisco de Holanda, 1923.
} 
Las correspondencias entre los textos calderonianos y las más importantes obras pictóricas, manieristas y barrocas, muchas de las cuales se encuentran en el Museo del Prado, demuestran el interés del poeta no sólo con respecto a las artes figurativas desde un punto de vista criticoestético sino también con respecto a las perspectivas filosofico-epistemológicas que están en la base de su rolélv. Estas perspectivas, platónica y estoicamente, atribuían a la visión, a la ilusión, a las sombras, al sueño, a la función del teatro — todas funciones deícticas de una vista mental ${ }^{8}$ tareas fundamentales y sapienciales en el desarrollo diegético del texto.

De hecho una comedia de sombras es la comedia mitológica El mayor encanto, Amor ${ }^{9}$, por los repetidos encantamientos que hacen las fisonomías evanescentes. En 1635 se estrenaba en la noche de San Juan la pieza en un estanque en el parque del Buen Retiro con tramoyas de Cosme Lotti instaladas en un islote ${ }^{10}$.

El valor icónico de esta pieza, pues, se manifiesta en los acontecimientos escenográficos que a través de la escaena ductilis reelaboran toda la codificación del teatro barroco.

Una verdadera zarabanda de fantásticas apariciones realizadas por una escenografia con muchos efectos de "cambios a vista» fue la puesta en escena de Los tres mayores prodigios en el patio del Real Palacio del Buen Retiro en presencia de Felipe IV. La comedia es la representación de tres famosos mitos.

Fuente iconográfica de la conquista del vellocino de oro podría considerarse la conocida pintura vascolar del IV siglo a.C. que se encuentra en el Museo Arqueológico de Nápoles.

La secuencia narrativa, análoga a la diégesis de la comedia calderoniana, muestra el vellocino que pende de los ramos de una encina totémica; Jasón en la actitud de robarlo; la serpiente que custodia el vellocino; y, en fin, Medea que intenta adormecerlo a través de un hechizo.

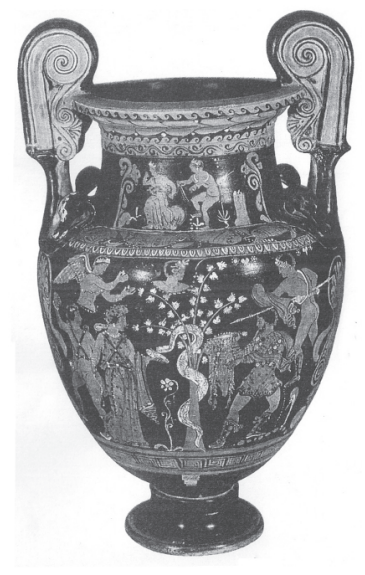

Imagen 1. Pintura vascolar siglo IV a.C. Museo Arqueológico de Nápoles.

${ }^{8}$ Arellano, 1995, pp. 411-442.

${ }^{9}$ Cito por la edición de Valbuenas Briones, 1966, Obras Completas I, Dramas. Todas las citas se refieren a esta edición con indicación de la página.

${ }^{10}$ Ver Cancelliere, 2001, pp. 117-118. 
Por lo que se refiere al mito de Hércules y Deyanira, el dramático instante representado en la tabla al óleo del Pollaiolo, (1470 ca) de esotérica simbología académica neo-platonizante, está evocado en los versos de Calderón en que se ve al centauro Neso que está huyendo con su presa apretada entre sus brazos,

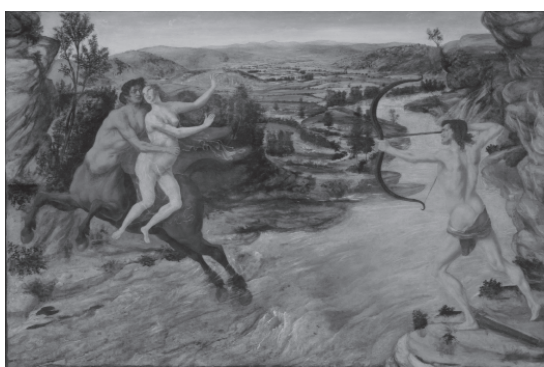

Imagen 2. Antonio del Pollaiolo, Hércules y Deyanira (1470 ca.). Yale University Art Gallery, New Haven. y al héroe que lanza la flecha envenenada contra Neso aun a riesgo de herir a su esposa:

HÉRCULES

Bellísima Deyanira, aquesta crueldad perdona: harto dilaté tu muerte; más ya tu vida ¿qué importa?

Ponzoña la flecha lleva: iguales las armas nota, bárbaro delfin supuesto que si en lid tan rigurosa tú me mataste con celos, yo te mato con ponzoña.

Tira adentro la flecha, luego vase NESO [Dentro] ¡Ay de mí; (p. 1581)

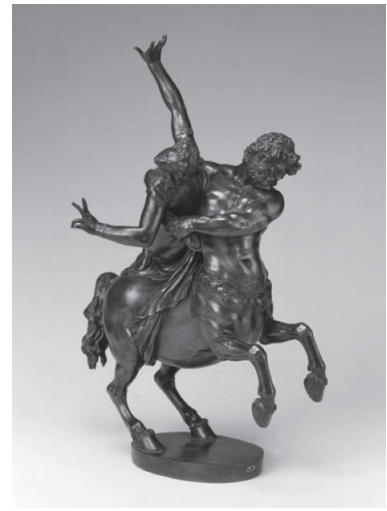

Imagen 3. Juan de Bolonia, Hércules y el centauro Neso $(1587 \mathrm{ca}$.) Museo de Dresde.
Es necesario recordar como fuente iconográfica la escultura de bronce del Giambologna (1587 ca, ahora en el Museo de Dresde) que muestra el momento culminante del rapto brutal, la huida al galope del centauro, los gestos de desesperación de la joven.Y en Calderón Deyanira exclama: "iCielos piadosos, dad favor a mis congojas", y luego «¡Cielos! ¿Qué estrella de cuantos / aquel azul manto bordan, / desperdiciadas cenizas / de la más luciente antorcha, / es la mía?» (p. 1582). 
El episodio de Teseo y Ariadna, que constituye el tema de la Jornada II, encuentra su momento culminante en el lamento de la joven al final del acto. Los prolongandos acentos de desesperación cargan los versos de una musicalidad que nos sugiere que el poeta se ha recordado del melodrama de Monteverdi la Arianna del 1608.

Es interesante constatar que en una obra maestra de Tiziano, Baco y Ariadna del 1520, se muestra lo que acaece después de la conclusión que ofrece Calderón: aquí Ariadna parece irse de la escena volviendo las espaldas — «vase» dice la acotación del textocuando el joven Baco irrumpe con su carro y parece que a voces la llame para refrenar su huida. El repertorio icónico relativo al lamento de Ariadna tendrá éxito, en cambio, en el Romanticismo y en el Simbolismo.

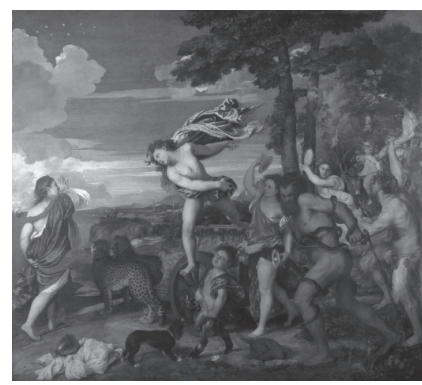

Imagen 4. Tiziano Vecellio, Baco y Ariadna (1520-1523) National Gallery de Londres.

La fiera, el rayo y la piedra, representada en el teatro del Coliseo en $1652^{11}$ y de la cual nos han llegado los bocetos de la puesta en escena que se representó en Valencia en 1664, publicados por Valbuena Prat ${ }^{12}$, es una libre reelaboración de varios mitos a través de un hilo conductor que plantea el tema del amor correspondido y del no correspondido.

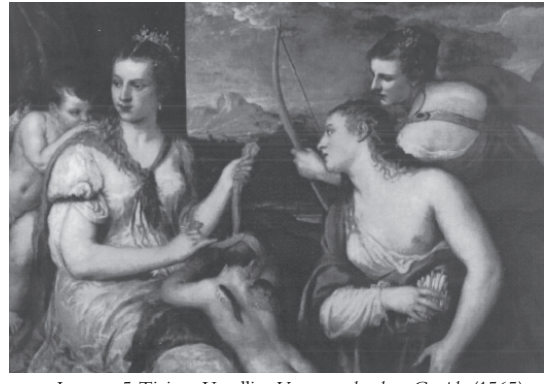

Imagen 5.Tiziano Vecellio, Venus vendando a Cupido (1565).

El mito, de influjo académico neo-platonizante, de la competición entre Eros, el amor pasional de los sentidos, y Anteros, el amor racional que aspira hacia el modelo absoluto, el Hiperuranio, recurre varias veces en Tiziano, por ejemplo en Venus vendando a Cupido.

Galería Borghese de Roma.

A través de una metáfora fuertemente icónica, el maestro, vuelve sobre el tema análogo de las dos Venus contrapuestas en la famosa alegoría de Amor sacro y Amor profano, donde la mirada seductora y cautivadora de la Venus Pandemia desnuda no llega a encontrar la

\footnotetext{
${ }^{11}$ Ver también Egido, 1989, ed. de La fiera, el rayo y la piedra.

${ }^{12}$ Valbuena Prat, 1930, pp. 39-41.
} 


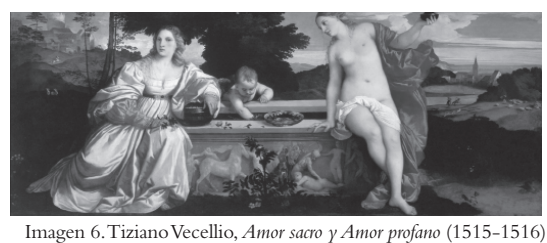

Imagen 6.Tiziano Vecellio, Amor sacro y Amor profano (1515-1516). Galería Borghese de Roma.

mirada pensativa e indefinida de la Venus Urania que resplandece en el candor luminoso de su pureza.

Resaltan, pues, de forma evidente, en el lienzo las Pathosforlmeln, - $\mathrm{O}$ sea las formas clásicas que construyen, gracias a una manera codificada, lo detalles para suscitar reminiscencias y pasiones, según la teoría de Warburg ${ }^{13}$ — el color rojo de las volutas de la capa de la Venus Pandemia que vuelve en las mangas farol de la Venus Urania como connotación del Eros; su pose voluptuosa que evoca todas las Nereidas en la grupa de un delfín o de un monstruo, como se ve en bajorrelieves de la Antigüedad; el pilón en que juega Cupido que evoca un sarcófago, etc.

El tema de Pigmalión y de su estatua viene de Ovidio y, aun antes de fábulas orientales, y está presente en muchas comedias y escenografias del teatro barroco donde la problemática del doble y del simulacro viviente es tema constante que se desarrolla en todas sus valencias simbólicas en el texto y en la escenografia. Objeto de culto y veneración, axis mundi, colocado en el fondo de las perspectivas, el simulacro puede representar también, como en este caso, el icono congelado del vivocadáver, es decir el elemento icónico y simbólico de la conmutación de la vida en la muerte y viceversa ${ }^{14}$. En el parlamento de la ingrata Anajarte, culpable de rechazar el amor, la palabra poética traduce de forma evidente el estremecimiento de la transmutación precisamente en el instante en que ya no es del todo mujer aunque pero todavía no es estatua. Los versos se articulan a través de dos tonalidades de recitación: la voz que remite a la mujer todavía viva y la voz quebrada, una voz interior, propia del aparte, cuyo contrapunto ineluctable habla mudo en la medida del tiempo de aquella trágica transformación en simulacro:

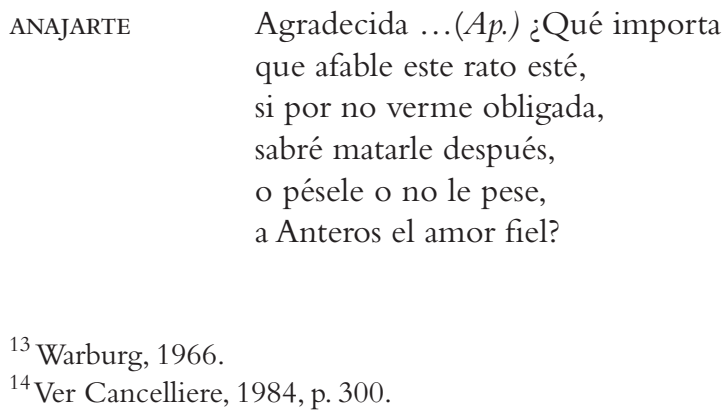




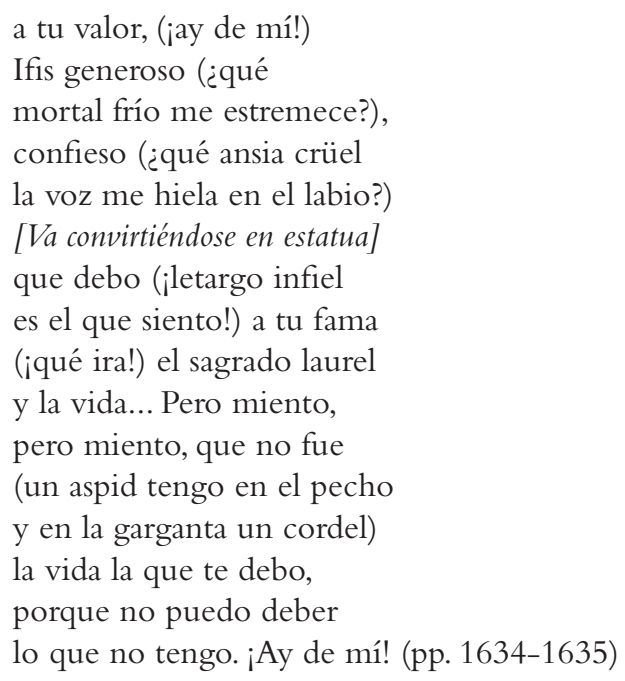

Y ahora el mármol apaga la palabra en la forma y la vida se hace icono inmutable, testigo de sí mismo sin memoria. En la realidad, al morir el ser humano no se hace mármol sino ceniza; sin embargo esta superrealidad de la poesía calderoniana corresponde, como hemos dicho, a una lógica más verdadera de la que nos ofrece la realidad empírica, y se traduce en una imagen más verdadera que lo verdadero, en este caso literalmente icono, en el sentido de que la poesía nos representa en el escenario el poder de la misma metáfora.

Fortunas de Andrómeda y Perseo se representó en 1653 en el Coliseo del Buen Retiro con las escenografias de Baccio del Bianco.

Momento fundamental de la diégesis es la historia de la bella Danae, hija de Acrisio rey de Argos, segregada por el padre a causa de un funesto oráculo, y a pesar de eso, fecundada por la lluvia de oro del divino Júpiter. Este mito es el tema de una de las "poesías" mudas de Tiziano, la Dánae de 1553, ahora en el Museo del Prado. A pesar de que existan otros ejemplares anteriores, es éste el que consideramos como la referencia inmediata para Calderón, como muestra el diálogo entre Danae y dos Damas al comienzo de la Jornada Segunda:

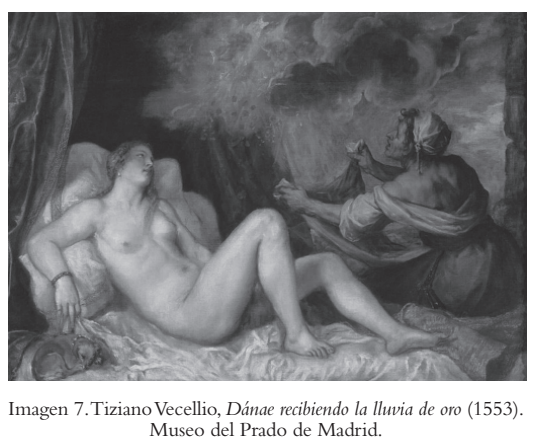




$\begin{array}{ll}\text { DanaE } & \begin{array}{l}\text { Oíd ¿que nuevo acento es } \\ \text { el que por los aires oigo? }\end{array} \\ \text { DAma 1. } & \begin{array}{l}\text { No sé, señora; mas sé } \\ \text { que aun eso no es el asombro. }\end{array} \\ \text { DANAE } & \text { ¿Pues qué? } \\ \text { DAma 1. } & \quad \begin{array}{l}\text { Que de la dorada } \\ \text { se viene abajo, lloviendo } \\ \end{array} \\ & \text { sobre nosotros el oro } \\ & \text { que le esmaltaba. }\end{array}$

DAMA 2. ${ }^{\mathrm{a}}$

Es en vano

que el que llevue, a lo que noto, es de más sagrada nube. (p. 1655)

Es interesante notar que el tema de la avaricia está evidenciado tanto en el lienzo como en el texto dramático. Aquí se ven a las damas disputarse codiciosamente cada moneda de oro incitándose recíprocamente y repetidas veces a «coger». De la misma manera la vieja criada ticianesca, avara y siniestra con prosaico realismo tiende su falda para coger lo más posible de las monedas. En ambos casos una mordaz escena de realismo dentro de una representación de un misterio divino.

De nuevo Calderón introduce en la diégesis una variante que, siendo de tipo meta-visivo, constituye un golpe de teatro. Mercurio y Palas, urden que su hermano Perseo vea en sueños su nacimiento de origen divino en la gruta de Morfeo, de manera que la visión pueda incitarlo a gloriosas empresas.

En el fondo de la caverna, pues, a través de una pantalla-espejo, según un topos barroco, le aparece al héroe durmiente la prodigiosa fecundación materna, así que, cuando despierta, ya no puede distinguir entre realidad e imaginación.

Perseo $\quad$ ¿Qué lóbrega estancia es ésta,
en cuyos cóncavos hondos
delirios son cuantos veo,
fantasías cuanto toco?
$[\ldots]$
Nada veo, nada oigo,
de cuanto veía y oía. (p. 1654)


El topos vuelve cuando, en La púrpura de la rosa, a Marte, en la gruta, le aparece la visión de los amores de Venus y Adonis. Sin embargo, a partir de lo que ve Perseo, se prefigura el valor analítico del sueño, por el hecho de que el héroe se va interrogando con ansiedad sobre su propio nacimiento.

Una vez más la música refuerza la visión en su paradójico iconismo: un coro por dentro entona unos retornelos que se alternan con los parlamentos de las Damas y de la misma Dánae, con un evidente efecto de «recitar cantando». Por consiguiente el espacio escénico de la visión se convierte en el lugar en que se refleja el eco, un eco barroco que es del espacio porque es propio de la estructura sonora. Las empresas heroicas de Perseo, según un climax en crescendo, se desarrollan en la Jornada Tercera.

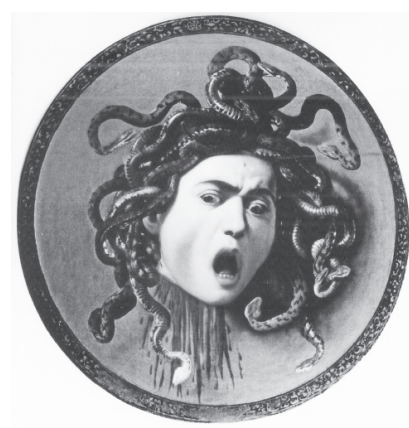

Imagen 8. Michelangelo Merisi da Caravaggio, La cabeza de Medusa (1596) Galería Uffizi, Florencia.

Es interesante la coincidencia iconográfica que pone en relación la comedia con la famosa «rotella», el escudo pintado por el Caravaggio en 1596 para el granduque Ferdinando de'Medici. Esta imagen de la cabeza cortada de la Medusa había circulado por toda Europa a través de reproducciones, y es imagen de fuerte entropía pictórica: una mirada, la mueca de dolor de la monstruosa criatura que la muerte ha fijado en el instante en que se mira a sí misma con horror en el escudo-espejo del héroe, con su enrollada melena de culebras y la sangre que va derramándose sobre los campos de Libia.Y así el poeta fija el icono del horror en el instante en que el monstruo se mira al espejo. Quizás sea éste el momento más intenso de la relación entre poesía y pintura: la mueca de dolor es verdaderamente el pintor "poesía muda» y en el poeta «pintura que habla».

Perseo ¡Medusa!

Medusa

¿Cuya eres, voz

Tan osada, que me llames

Cuando otras me huyeron?

Perseo

Vuelve

Los ojos.

Medusa $\quad Y$ en ellos tales

Iras, que ellas te escarmienten 
de osadía semejante.

Enséñale [Perseo] el espejo.

Medusa ¡Ay infelice de mí!

¿Qué es lo que miro?

Perseo

Tu imagen.

Medusa

$[\ldots]$ ¿Ésta soy yo?

Perseo

Sí, ésta eres.

MedeA

¿Qué mucho que a todos mate, Si aún me da la muerte a mí

El horror de mi semblante?

¡Qué horrible forma! ¡Qué fea!

¡Qué asombrosa! ¡Qué espantable!

[...]

Perseo Si das la muerte a quien miras,

Mírate a ti. (p. 1672)

La furibunda persecución de Perseo en contra de Medusa termina con la imagen de la sangre derramada sobre los campos generando culebras y con la cabeza cortada en el tablado.

El episodio de Andrómeda se desarrolla a través de repetidas referencias icónicas acompañadas por la música. Se trata de formas estereotipadas: el lamento de Andrómeda encadenada sobre un escollo durante una tempestad de mar, evoca el de Ariadna abandonada, famoso prototipo monteverdiano; el coro de Nereidas que exultan alrededor de la joven, etc. El paisaje que acoge a Andrómeda abandonada está atravesado por el eco que difunde entre tierra y mar sus lamentos. Y he aquí que aparece de repente el horroroso monstruo, autómata de teatro, como dice la acotación: «Sale la fiera toda de escamas». Sin embargo las quejas de Andrómeda terminan al llegar de Perseo; informa la didascalia: «Aparece Perseo, en el caballo, en lo alto, con lanza y escudo». Los parlamentos de Andrómeda y Perseo abundan en descripciones que derivan de una muy rica tradición iconográfica manierista y barroca. Un lienzo de Paolo Veronese, segunda mitad del Quinientos, es interesante por el particular

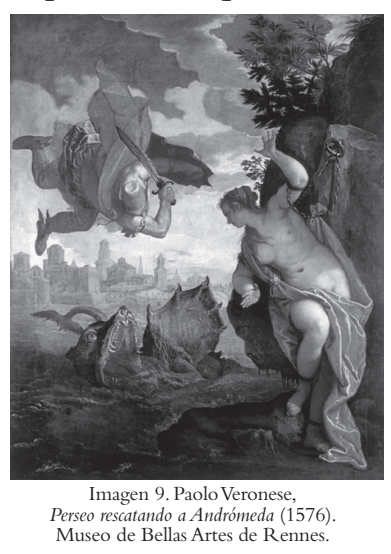




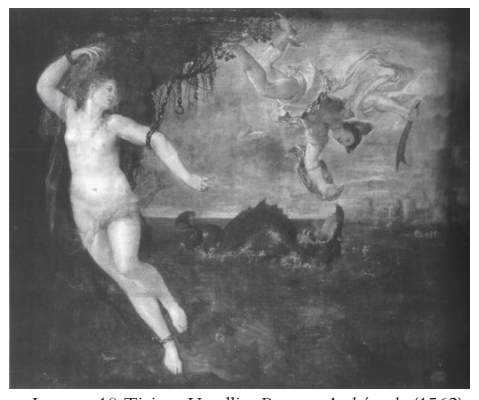

Imagen 10. Tiziano Vecellio, Perseo y Andrómeda (1562). Wallace Collection en Londres.

del cuerpo desnudo de la joven adornado por una purpúrea capa sacrificial. Según la tradición mitológica aquí el héroe llega volando gracias a los calzados alados que le había donado Mercurio. También en el Perseo y Andrómeda de Tiziano (1562) campea en primer plano el blanco cuerpo totalmente desnudo de la joven encadenada que contrasta con la tenebrosa imagen del monstruo que sale de las aguas; mientras Perseo llega en vuelo desde lo alto. En cambio, Hans von Aachen, realiza el precioso alabastro del 1603, que se encuentra en el Alcázar de los Austrias en Innsbruck. Aquí Perseo aparece en vuelo bajando de las nubes a la grupa del caballo alado Pegaso, igual que en Calderón. De hecho dice el héroe:

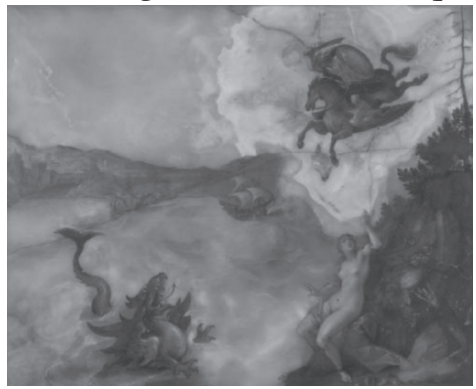

Imagen 11. Hans von Aachen, Perseo y Andrómeda Museo de Historia del Arte de Viena.

Perseo Alado Belerofonte,

Bruto y ave en piel y pluma, que aborto fuiste engendrado de la sangre de Medusa, Baja el caballo Abate el vuelo a esas ondas. (p. 1677)

Es probable que en ambas obras se está evocando el episodio ariostesco de Angélica, cuando el paladín Ruggero, llegando en vuelo sobre el hipogrifo, la salva del monstruo.

La comedia termina con la aparición de Júpiter en un sol, en traje de Cupido tal como le había aparecido a Dánae después de haberla fecundado. Ahora, habiendo reconocido a su hijo Perseo, desvanece hacia la esfera de la sublime música celeste, fuera de la escena.

Muchos son los triunfos de Zeus en la iconografia, sin embargo hace

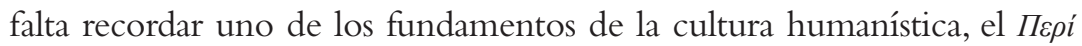

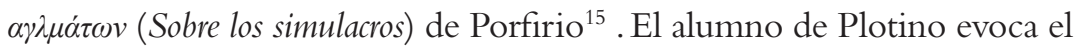

${ }^{15}$ Porfirio, 2012, pp. 147-150. 
simulacro por excelencia que es la enorme estatua criselenfatina de Zeus triunfante en su trono, obra de Fidia venerada en toda la Antigüedad y colocada en el templo de Olimpia. Es interesante recordar que en su comentario Porfirio aclara el valor simbólico de nácar y del oro en los simulacros.

Sin embargo, todas las apoteosis finales de los dioses, en el teatro de Calderón - por ejemplo el triunfo del Amor correspondido como colofón de La fiera, el rayo y la piedra;Venus y Adonis elevados a constelaciones en la gloria inmortal de su amor; Cupido que, al aparecer como Deus ex machina, proclama el triunfo del Amor al final de Fineza contra fineza; las bodas de Prometeo y Pandora celebradas por el mismo Apolo, en la explosión final de la "fiesta» en toda su ilusoria espectacularidadsintetizan siempre los valores connotativos de la manifestación en la escena del simulacro de Zeus. Ésta hay que entenderla también en su valor metateatral, puesto que cada triunfo de los dioses es metáfora del de la Corte y de su monarca, restauración de la justicia y de la paz en tierra y en el universo todo. En fin, en estas portentosas apariciones realizadas por medio de complejas maquinarias, iluminotécnica, y música, la Corte se reflejaba llevando a cabo su procedimiento de autocelebración.

El mito de Andrómeda y Perseo fue representado en muchas Cortes europeas por los grandes efectos de espectacularidad y la música. El Perseo de Lope de Vega, publicado en 1621, incluía partes en música. Por cierto Calderón tenía noticia del éxito de la Andromède de Corneille, representada en 1650, en la corte de Louis XIV con significativas partes en música de Dassoucy; y Lulli parece que se inspiró en Calderón en su Persé de 1682. Lo que acabamos de decir parece confirmar, en fin, la síntesis de poesía, música e iconicidad escénica que se ha desarrollado en torno a este mito.

El divertido altercado entre Apolo y Amor, en El laurel de Apolo, acompañado por música, disputando por la empresa de asesinar a la serpiente Pitón, ya se encontraba en un lienzo de Cornelis de Vos Apolo y la serpiente Pitón (1636-1638, ahora en el Museo del Prado).

En un paisaje arcádico está representado Apolo que, con una capa de color rojo y circundado

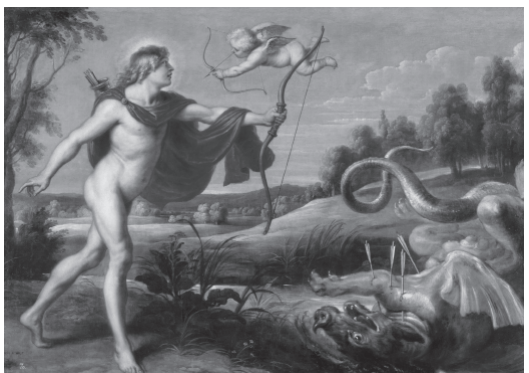

Imagen 12. Cornelis de Vos, Apolo y la serpiente Pitón (1636-1638). Museo del Prado de Madrid. 
por una aureola dorada, con los miembros tendidos, va lanzando flechas mortales en contra del monstruo que aterroriza la Tesalia; a su vez es amenazado por el niño alado, Amor, con sus flechas. Es interesante recordar que una idéntica iconografia de Apolo y del monstruo se encuentra en los bocetos que el Buontalenti realizó para los Intermezzi de $1589^{16}$.

Sin embargo, en Calderón la escena del duelo a muerte entre Apolo y Fitón está representada a través de una palabra poética que, se hace pictórica ofreciendo a los ojos de la mente del lector/espectador - $\pi \rho \grave{o}$

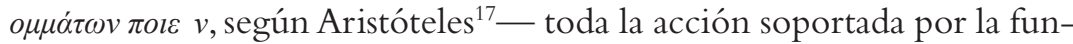
ción prosémica de la ticoscopia. De hecho Libia hace el relato de lo que está viendo fuera de la escena informándonos no sólo sobre lo que está acaeciendo sino que, gracias a la écfrasis, sus palabras dejan ver, de esta lucha entre Apolo y Fitón, hasta los detalles trágicos: la monstruosidad de la serpiente con sus navajas de marfil; el tiro del arco de Apolo:

Libia $\quad[\ldots]$
\[ \begin{array}{l}\text { iQué tiro tan feliz! } \\ \text { Que falseando a la escama } \\ \text { las conchas que bruñir } \\ \text { pudo, al temple del sol, } \\ \text { del aire esmeril, } \\ \text { al corazón penetra, a cuyo tiro vi, } \\ \text { revoloteando el ala } \\ \text { de la enhiesta cerviz } \\ \text { el crinado copete } \\ \text { desmenelar la crin (p. 1749). }\end{array} \]

El acmé se consigue con la visión de la sangre derramada del monstruo que va transformando la vida en muerte a través de codificadas metáforas cromáticas, hasta derrumbarse en las entrañas de la tierra, ahora su túmulo.
LIBIA
$[\ldots]$
Por boca y por heridas
ya verter, ya escupir
de venenosa nieve,
de infestado carmín
${ }^{16}$ Ver Botto, 1968.
${ }^{17}$ Aristóteles, Retórica, 1996, pp. 332-333, v. 1411a. 


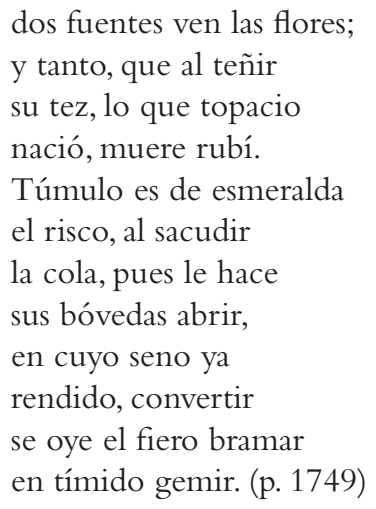

En la Jornada Segunda se cuenta el mito de Dafne y Apolo. La escena de Dafne perseguida por el anhelante dios se desarrolla a lo largo de excitados parlamentos en forma de recitativos que imitan la fuente ovidiana hasta reproducir el mismo pathos en las invocaciones desesperadas de la ninfa: «¡Dadme vuestro favor, dioses!». $\mathrm{Y}$ poco antes la patética peroración dirigida por Apolo a Dafne recuerda el famoso verso ovidiano: «iNympha, precor, Penei mane! Non insequor hostis Nympha, mane. [...]»" La acción, que se desarrolla a través de una alternancia entre recitativos y retornelos melódicos, nos deja ver a Apolo corriendo jadeante

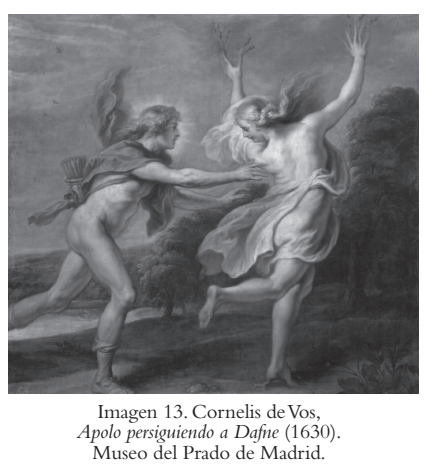

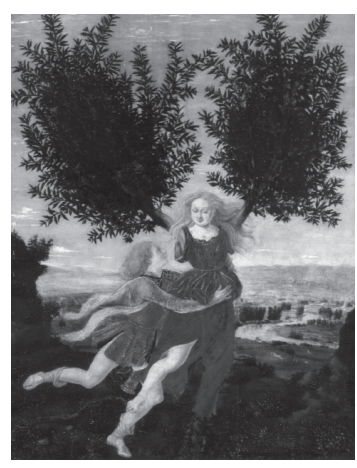

Imagen 14. Antonio del Pollaiolo, Apollo y Dafne $(1480 \mathrm{ca}$.).
National Gallery de Londres.

y con el brazo tendido hacia su amada Dafne a la cual, suplicante, grita: «Detente», detalle ya visualizado por Cornelis de Vos en Apolo persiguiendo a Dafne (Museo del Prado). Cuando el dios la alcanza, por fin, en la cumbre de un monte, sus brazos ciñen miembros que se van transformando trágicamente en ramos: «iHados! ¿Qué prodigio es éste? / ¡La beldad que a abrazar iba / entre mis brazos, convierten / en yerto tronco los dioses, / que de su llanto se duelen!» (p. 1761).

Ya una famosa pintura al óleo Apollo y Dafne (1480 ca) del Pollaiolo muestra precisamente

18 Ovidius Naso, Metamorphoseon Libri XV, I, vv. 504-505. 


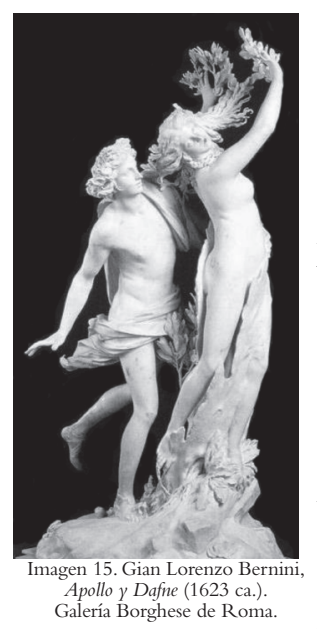

en la cumbre de un monte, como en Calderón, el acmé de la persecución que acaba con el abrazo del dios y la transformación de la ninfa en árbol. Sin embargo, el más pregnante ejemplar icónico es el grupo marmóreo Apollo e Dafne de 1623 ca. de Bernini (ahora en el Museo Borghese).

La obra en dos Jornadas de Calderón y música de Hidalgo se representó en el Real Coliseo del Buen Retiro en 1658. Si Calderón concibió El laurel de Apolo como una representación-música probablemente se debe al gran éxito hacia finales del Quinientos de la Dafne de Yacopo Peri (libreto del Rinuccini), que se considera como el primer melodrama de la Camerata de' Bardi.

El poeta llega a la ópera en música gracias al ejercicio de una poesía que carga las palabras de una pluralidad de significaciones que principalmente son sonoras, así que el oído percibe de manera concreta, aliteraciones, asonancias, onomatopeyas, ritmos, es decir un sonido que por ingenio del poeta se hace música ${ }^{19}$. Sin embargo, en la concepción de la Camerata de' Bardi - posible fuente de inspiración para el poetalas palabras construían la articulación del sentido y del ritmo, y por lo tanto era imprescindible la necesidad de su exacta interpretación. En cambio, en la creación poética el ingenio del autor las construye a través de artificios retóricos y preciosas metáforas puesto que ahora es el sonido que se hace imagen a través de la música, según una concepción, de ascendencia platónica, que anhela llegar a las esencias ideales y a sus interconexiones.

Todas estas consideraciones bien se ajustan a La púrpura de la rosa, que se representa en1660 en el Palacio Real con ocasión de las bodas de la Infanta María Teresa de Austria con Louis XIV ${ }^{20}$.

Una vez más, el poeta interpreta de manera libre la «fabula»: Adonis decide sacrificarse en defensa de la humanidad, renunciando al amor de Venus. Este sacrificio se explica con el hecho de que Adonis, obrando heroicamente, intenta librarse de la culpa de su nacimiento, siendo hijo de un amor incestuoso.

${ }^{19}$ Sobre el tema de la música en el teatro de Calderón, ver Sage, 1956, pp. 275-300; Querol Cavalda, 1981; Becker,1989, pp. 353-363.

${ }^{20}$ Sobre el teatro de corte, ver Arellano, 2000. 
En un teatro de bosque, el poeta plantea desde el comienzo de la obra, el desdén del joven respecto a las lisonjas amorosas de Venus que había salvado del asalto del feroz jabalí. El bello Adonis, desmintiendo el mito que le pinta como un joven débil y desdeñoso de amor a causa de su inmadurez y narcisismo, actúa, en cambio, como un joven atrevido que rechaza el amor de la diosa para que triunfe su valor.

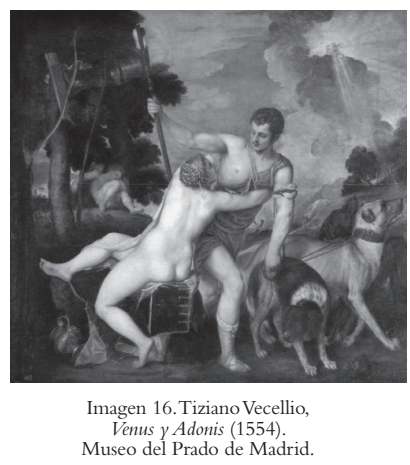

$\begin{array}{ll}\text { Adonis } & {[\ldots]} \\ & \text { Pues, perdona, que aunque sea } \\ & \text { mi más heroico blasón } \\ & \text { haberte dado la vida, } \\ & \text { triunfo ha de ser no menor } \\ & \text { no darte aplauso, porque } \\ & \text { veas que Adonis llegó } \\ & \text { solo en el mundo a lograr } \\ & \text { en una victoria dos. (p. 1767) }\end{array}$

«Yéndose», informa la acotación. El desdén de Adonis que rechaza a la diosa huyendo era ya un topos figurativo. De hecho, en el lienzo, Venus y Adonis (1553) de Tiziano, la torsión del cuerpo del joven, en actitud de librarse del abrazo sensual de Venus, visualiza la acción teatral. En el fondo Cupido, adormecido, está olvidado de su tarea, puesto que arco y flecha están colgados en las ramas de un árbol. En lo alto, en el cielo, aparece en su esplendor el carro de Venus como presagio de la apoteosis final de los dos. De color rojo son la túnica de Adonis y los calzados de cuero: color símbolo del amor pasional, del cual es objeto, pero al mismo tiempo de la sangre y del sacrificio. Color, pues, que en la iconografia y poesía clásicas connota al héroe en cuanto víctima predestinada para la regeneración de la Humanidad. Muy significativa es la torsión dinámica que fija a la diosa en su vano esfuerzo de llegar a ceñir con sus brazos el cuerpo de su amado. Se trata de un elemento de Pathosformeln ${ }^{21}$ de origen clásico que caracteriza a muchos personajes femeninos de la pintura del manierismo renacentista a partir de Michelangelo, Raffaello y luego Rosso Fiorentino, etc.

${ }^{21}$ Ver Didi-Huberman, 2004, pp. 11-27. 
Aquella torsión, pues, es la connotación del amor pasional no correspondido.

A finales del siglo Xvi el mito ya se encontraba en un lienzo de Annibale Carracci, Venus, Adonis y Cupido, que pertenecía a las Colecciones Reales. Aquí, pero, el cuerpo desnudo de Venus se fija en una torsión contraria con respecto a la de la Venus ticianesca connotando ahora la postura de la mujer rechazada, mientras el joven cazador va

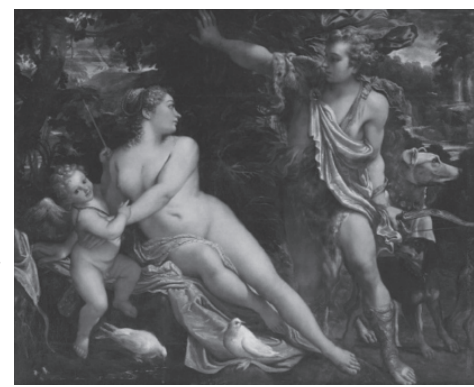

Imagen 17.Annibale Carracci,Venus, Adonis y Cupido (c. 1590). Museo del Prado de Madrid. alejándose con un ademán resoluto.

En Calderón, a pesar de que llegue a enamorarse de la diosa, el trauma de su nacimiento, que Adonis denuncia como causa de su imposibilidad a amar, es el motor de la acción trágica, como se desprende del cuento que hace a Venus:

ADONIS $\quad[\ldots]$
En sus últimos alientos
los dioses compadeció,
convirtiéndola en un árbol,
de cuyo llorado humor,
guardando el nombre de mirra
nací bastardo embrión,
maldecido de mis padres,
y con tan gran maldición,
como que de un amor muera.
Considere tu atención,
si en mi horóscopo primero
aborto de un tronco soy;
si después llevo tras mí
el heredado temor
de que de amor muera, puedo
no aborrecer el Amor. (pp. 1767-1778)

Este mito había fascinado al mismo Tiziano que lo había realizado en una pintura al óleo sobre madera como ornamento de un cajón (ahora en el Museo Cívico de Padua), El nacimiento de Adonis. En la parte central del tableau Lucina, diosa del parto, saca al neonato del tronco del árbol en que se había transformado Mirra culpable de un amor incestuoso y por esto, mal- 


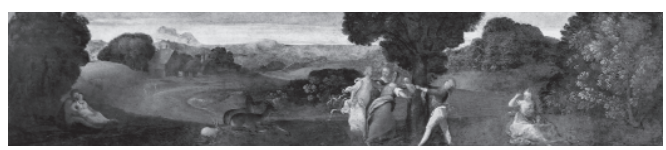

Imagen 18.Tiziano Vecellio, Nacimiento de Adonis (1506-1508) Museo Cívico de Padua.

decida por su mismo padre. Interesante el valor diegético de este tableau que desarrolla el mito a lo largo de un eje temporal entre pasado, presente, futuro: en la parte izquierda se ve la escena del amor incestuoso de los dos amantes; en el centro el trágico nacimiento de Adonis; en la parte derecha en cambio campea Venus.

De esta manera la pintura, "arte del espacio», imitando la poesía, se hace "arte del tiempo", mediante el recurso a un artificio que ya habían experimentado lo Antiguos desarrollando a lo largo de un solo tableau la narración que Calderón, en cambio, desarrollará a lo largo de la diégesis a través de varios parlamentos.

Otro lienzo de las Colecciones Reales, el de Venus y Adonis de Paolo Veronese que, según lo que se cuenta, Velázquez compró en Venecia por encargo de Felipe IV (Museo del Prado), podría haber inspirado una escena de la pieza calderoniana.

En el cuadro se ve al joven que se adormece reclinado en el regazo de la amorosa diosa. También aquí, según la iconografia,Adonis lleva túnica y calzados de color rojo, mientras queVenus se vuelve a mirar, anhelante, a Cupido que trata de inmovilizar uno de los perros

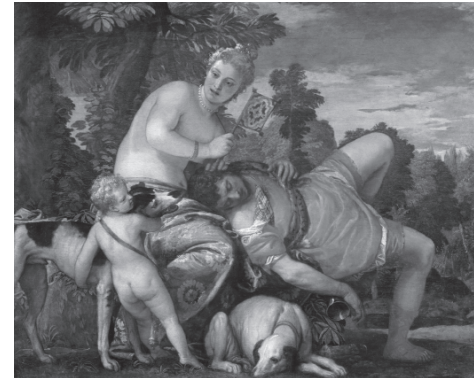

Imagen 19. Paolo Veronese, Venus y Adonis (1580) Museo del Prado de Madrid. impaciente por ir a cazar. La falda de la diosa, en color azul bordado en oro, parece simbolizar la esfera celeste, mientras las luces del día van apagándose en las sombras de la noche, como presagio del inminente ocaso de aquella pasión.

Y en el texto poético, gracias a la écfrasis, las palabras pintan la escena:

MARTE

$[\ldots]$

Sobre el ameno tapete, que en varios lazos dibujan cuadros de flores y fuentes, ella se reclina y él en su regazo se duerme, cuyo blando sueño guardan todas sus ninfas. (p. 1777) 
Sin embargo aquí está describiendo la escena el celoso dios Marte que la ve refleja en un espejo, descubierto por el Desengaño en el fondo oscuro de una caverna iniciática.

El dios llega a la visión reveladora en un contexto que se construye a través de elementos propios de una «fabula» esotérica: un antro misterioso, un dragón que desempeña el papel de monstruo-sapiente, una revelación que, sea realidad o engaño, desvela la verdad.

La escena virtual del antro, la escena del sueño, producida a través de efectos ilusionísticos, se reproduce, luego, realmente en la supuesta "verdad escénica», como explícita la didascalia: «Cúbrese la gruta y vense los jardines, y Venus sentada, Adonis en sus faldas, y las Ninfas: Chato y Celfa». (p. 1777)

Sin embargo, lo que nos parece interesante poner de relieve es la modalidad barroca de la visión dentro de la visión que recuerda la practicada por Corneille en su Ilusion Comique; pero, en el texto calderoniano, con un valor connotativo adjunto, la visión se ofrece como un tableau, tanto si debemos considerlo mental y construido por el poeta a través de distintas reminiscencias del mito, o como inspirado por la influencia del tableau del Veronese. Y puesto que Marte ocupa nuestro lugar de espectadores, duplicándolo en el escenario, es evidente el valor meta-icónico que instaura un juego de espejos propio de la manera de Velázquez en Las Meninas. Además, en el espacio oscuro del antro se encuentran unos personajes/espectadores: el Desengaño, la Envidia, La Ira, la Sospecha, es decir las personificaciones de los sentimientos mismos que se disputan el alma del dios mientras está mirando aquella visión, para él tan dolorosa. El problema de la revelación del icono, según la función meta-icónica, en Calderón llega a incluir la representación de las pasiones que afectan a quién está mirando. Por otra parte, poco antes, el mismo Calderón nos había enterado sobre los significados del ver y contemplar lo divino que el icono formula.

Adonis es herido por una flecha de Cupido cuando instaura con Venus un diálogo de tipo heurístico:

$\begin{array}{ll}\text { Venus } & \text { ¿Pues no me viste entonces? } \\ \text { Adonis } & \begin{array}{l}\text { Confieso que te vi; } \\ \text { pero no te miré. }\end{array} \\ \text { Venus } & \text { ¿Y hay cómo distinguir } \\ & \text { el ver del mirar? }\end{array}$


Adonis

¿Pues

hay quien ignore...

VENUS

Di.

AdONIS

...que el ver es solo ver, y el mirar advertir?

VENUS

Y bien, ¿qué es lo que adviertes?

Adonis

Que te llevas tras ti en tus rizos del sol todo el dorado ofir, del aura en tus alientos todo el humo sutil, que en destiladas gomas cualquiera es ámbar gris. (p. 1772)

El parlamento de Adonis se desarrolla a través de la canónica enumeración barroca de los elementos simbólicos del cosmos, espejos de la belleza de la diosa; de esta manera, en la base del debate sobre la visión la fábula de este amor divino logra toda su significación cósmica, cíclica y regeneradora.

El valor de ese carácter cíclico se condensa en una sola imagen de un fresco del Domenichino del Palazzo Durazzo Pallavicini de Génova. La obra es de 1630 pero es improbable que Calderón la conociese, por lo tanto la coincidencia en la interpretación del mito se explica por el hecho de que ambas obras remiten a un común patrimonio hermenéutico: en el fresco, mientras un detalle evidencia la silueta del jabalí, símbolo del invierno que se va alejando, en primer plano Adonis yace muerto; resaltan sus blancos miembros mientras a su alrededor se esparcen rojos pétalos; Imagen 20. Domenico Zampieri, Muerte de Adonis (1629-1631). semejante oximórico cromatismo

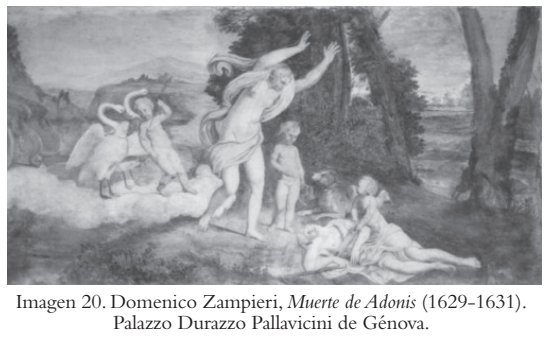
connota, de forma especular, a Venus que, desnuda con su candor níveo y drapeada de rojo, se precipita, con los brazos levantados, trastornada por la dolorosa vista de tanto horror. También en Calderón Venus sale, suelto el cabello medio desnuda, pero con las manos ensangrentadas, implorando fuertemente afligida: «[...] Pastores, / decidme (¡ay de mí!), decidme / si dijeron unas voces / ¡Piedad, cielos!””. (pp. 1781-1782). 
Sin embargo, ¿cómo es posible esa imagen de la diosa con las manos ensangrentadas, si ansiosa quiere conocer quién sea la víctima y si hasta ahora no ha llegado a ver el cuerpo herido de su amado? La explicación consiste en el hecho de que el «deber ser» poético, en que se funda el icono, llega a construir el tableau en su totalidad, gracias a la compresencia de todos los elementos simbólicos, prescindiendo de la realística sucesión temporal y causal, exactamente como puede verse en la pintura vascolar o en los bajorrelieves cíclicos. Por consiguiente el tableau está fijado para siempre, y por eso Venus acude hacia el cuerpo de Adonis agonizante «ensangrentadas las manos». Tanto en el texto poético como en el pictórico la simbología de los pétalos de rosas se da, según la acepción de la Escuela de Warburg, como didascalia del mito en su valencia neo-platónica ${ }^{22}$.

El mitema icónico se ofrece a la vista en su desarrollo metamórfico en insistidos retornelos: "con su sangre les infunde / nuevo espíritu a las flores»; «tanto que de las animadas, / cada flor es un Adonis»; ( p. 1783) hasta llegar a la imagen, propia del Pathosformeln, de Venus desgarrada por el dolor, visualizada por las palabras del Coro:

$\begin{array}{ll}\text { Todas } & \text { Con la fuerza del dolor } \\ & \text { Cayó desmayada sobre } \\ & \text { Las rosas, y sus espinas } \\ & \text { Van violando sus colores... (p. 1783) }\end{array}$

Las simbologías poéticas y cromáticas, en fin, han fijado el tableau del sacrificio. Sin embargo, la apoteosis astral de los dos amantes que en fin brillan como una sola estrella, es anuncio de un orden del cosmos que ineluctablemente está gobernado por el retorno cíclico.

El hijo del sol, Faetón se representa en 1661. Con respecto a esta comedia mitológica la referencia icónica más directa es un lienzo de Jan Carel Van Eyck de 1632 La caída de Faetón (Museo del Prado).

Aquí el héroe está precipitándose arrojado fuera del carro del sol arrastrado sin gobierno por los cuatro caballos desbocados. El joven atrevido está envuelto en una capa roja movida por el aire;

${ }^{22}$ Ver Panofsky, 1975.

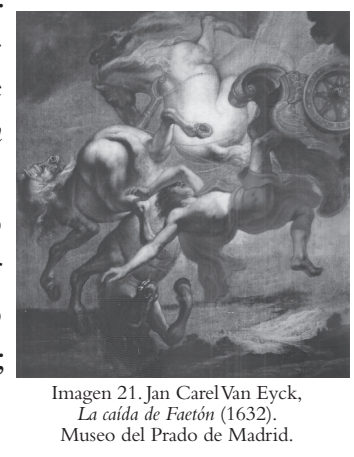


la torsión de su cuerpo desarticula los miembros descompuestos a causa de la trágica caída. El gesto del brazo intenta cubrir la cara a la mirada del padre por la vergüenza por no haber cumplido con su empresa, que su mismo padre le había encargado. Los cuatro caballos blancos se precipitan, junto al cuerpo de Faetón y el carro, por elípticas trayectorias vertiginosas. En este vórtice matizado en rojo, blanco, oro, en el fondo azul del cielo se evidencia la entropía simbólica de un cataclismo cósmico.

Y Faetón en el texto calderoniano se presenta como un héroe; por tanto no por arrogancia en contra del padre, sino por un valiente atrevimiento — salvar a Tetis raptada por Épafo-, aunque todo acabe en una ruina total. En un teatro de fuego, pues, la ruinosa caída se visualiza concretamente en el escenario a través de análogas connotaciones de iconismo barroco:

FAETón
\[ \begin{array}{l}\text { Mas ¿ qué es esto? Los caballos } \\ \text { desbocados y furiosos } \\ \text { viéndose abatir al suelo, } \\ \text { soberbios extrañan otro } \\ \text { nuevo camino...Y no, jay triste!, } \\ \text { En esto resulta solo } \\ \text { el desmán, sino en que ya } \\ \text { la cercanía del solio } \\ \text { de la ardiente luz de tantos } \\ \text { desmandados rayos rojos } \\ \text { montes y mares abrasa } \\ \text { [Descúbrese el teatro de fuego que será de chozas y árboles } \\ \text { abrasados] (p. 1901) }\end{array} \]

En la tradición icónica del mito destaca una pintura de 1635 de Nicolas Poussin (Staatliche Musee, Berlín) de evidente carácter narrativo como sugiere el título: Apolo concede a Faetón la guía del carro. La diégesis pictórica nos muestra al joven de rodillas en presencia del áureo dios-padre, rodeado por los dioses del Olimpo y bajo el arco iris de resplandeciente color oro, rogándole que le otorgue la guía de su carro. No sabemos si Calderón conociese la obra de Poussin, sin embargo es interesante notar la circulación de topoi iconográficos como fundamento de una simbología de

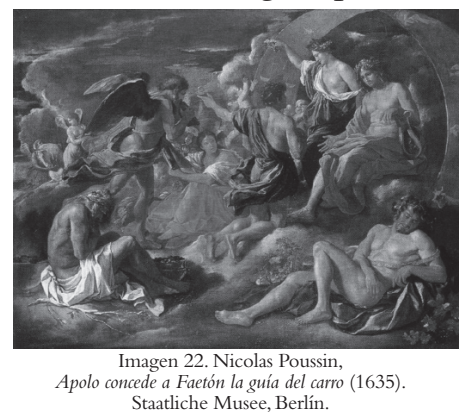


toda la época. De hecho en el texto poético se ve a Iris resplandeciente que lleva volando al héroe hasta el trono del sol-Apolo, y la diégesis desarrolla la narración análogamente a la de Poussin. En 1683 en la Corte de Francia se representa el melodrama Phaetón de Lulli, probablemente influenciado por Calderón. Sin embargo, ya en 1630 en Roma en la corte de los Barberini, Johann von Kapsberg representaba con éxito su Fetonte, melodrama en el estilo de la Camerata, en la presencia de muchos representantes de la nobleza española.

La zarzuela Eco y Narciso de 1661 se desarrolla en una melancólica Arcadia. A través de un decorado verbal, de exquisito preciosimo gongorino, se representa la tragedia de Narciso que, a causa de la tiránica madre Liríope, más obsesiva que Tetis en El monstruo de los jardines, se ha convertido en una fiera humana, y como Segismundo, es forzado a vivir en las profundidades de una gruta que se abre dentro de una tupida selva inaccesible. Luego el mismo Narciso va a refugiarse en un monte abrupto y escarpado para huir de la bellísima Eco, aunque la desee desesperadamente.

Reelaborando la narración de Ovidio ${ }^{23}$, Calderón hace que los dos jóvenes lleguen a su ineluctable destino: envenenada por la celosa Liríope, Eco pierde la facultad de hablar, y su süave voz sólo puede repetir las últimas sílabas de lo que oye; Narciso asomándose a una fuente, bebe en ella, y, viendo su misma imagen, que cree ser de una ninfa aún más bella que Eco, se enamora:

$\begin{array}{ll}\text { Narciso } & {[\ldots] \text { ¿Quién vio }} \\ & \text { jamás igual hermosura } \\ & \text { de la que aquí a mirar llego, } \\ & \text { pues su ninfa (iqué ventura!) } \\ & \text { llechando está vivo fuego } \\ & \text { dentro de la nieve pura? (p. 1932) }\end{array}$

El largo y delirante diálogo con la imagen reflejada en la fuente se interrumpe con la llegada de Eco la cual también se refleja puesta al lado de la imagen de Narciso. Éste, viéndola en la superficie de las aguas y al mismo tiempo en la realidad, se queda pasmado:

NARCiso ¿Cómo estás aquí, si estás en el cristalino alcázar

${ }^{23}$ Publius Ovidius Naso, Metamorphoseon Libri XV, Libro III, vv. 339-510. 


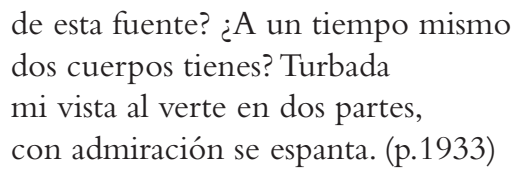

Pero la joven va desvaneciendo y reduciéndose sólo a una voz en eco. Luego llega a la fuente también la madre Liríope que, puesta a su lado, reflejándose en la fuente le desvela el engaño:

Liríope Pues de esa misma manera que a mí me miras, te ves. La que juzgas deidad es sombra tuya Considera si ha sido tu amor locura, pues a sí mismo se amó. (p. 1938)

Pero Narciso, precipitado en el vórtice de una pasión imposible por su misma imagen, se muere de una atroz pena.

Esquema admirable, éste de la formación de la imagen en el espejo que en la metáfora poética constituye el prototipo de aquel que será el esquema analítico: la mirada de la madre converge en la misma imagen en que el sujeto se refleja mientras la mirada del Otro se difunde como espacio en que la visión se realiza: aquí la voz de Eco. Warburg considera esta relación entre mito y análisis el punto de partida para la elaboración de la iconología como ciencia.

En Eco y Narciso, además, la música articula la deixis del espacio y del tiempo ${ }^{24}$. Uno y otro se refractan y se reflejan y en fin se hacen metafisicos y cósmicos, gracias a la "música en eco».

Esta articulación espacio-temporal connota también el caos laberíntico que construye a los personajes en la esquisis cuerpo-voz, o bien en la perversión de su imagen amada al espejo: connotación última del mundo-espejo, encantado, melancólico de resonancias errantes, animadas por un deseo que anhela a su objeto. Así, por ejemplo, cuando Narciso pregunta a sí mismo con quién está hablando mientras dialoga con las últimas sílabas que repiten sus propias preguntas ansiosas:

NARCISO ¿Qué preguntas si me hablas?

Yo soy Narciso.

${ }^{24}$ Arellano, 2001. 
ECO

Narciso.

NARCISO

Sí. ¿Qué te espantas?

ECO

¿Espantas?

NARCISO

Pues, ¿no he de espantarme yo,

Al ver en tí tal mudanza?

¿Qué ibas diciendo?

ECO

¿Diciendo?

NARCISO

Sí, no calles nada.

ECO

Nada.

(Aparte) (Pero miento, que mil cosas

Voy a decir y turbada

La lengua sólo pronuncia

Lo que oye). (p. 1934)

En el Aparte la voz de la joven, en cambio, se difunde en el pose icónico del «canto a fermo» de una aria que el público podía oír pero imaginándola muda, llanto y pensamiento interior sin voz, y que viene de una imagen bellísima que, a su vez, no podía ver sino sólo imaginar.

Sobre estas correspondencias y divergencias entre la vista, el oído y la mente se construye toda la pièce como elaboración meta-icónica en la formulación de las imágenes.

Entre las muchas iconografias del mito debemos recordar Narciso de Jan Cossiers 1636-1638, (Museo del Prado). Aquí el joven, con los miembros color nácar y un drapeado color rojo, según el tópico icónico, se mira en la fuente con tanta ansia que no puede desviar su mirada de su imagen.

Sin embargo, parece evidente la influencia de la obra maestra del Caravaggio, Narciso en la fuente 1599 (Galleria Nazionale, Roma). La fuerte torsión del cuerpo expresa la pasión amorosa hacia su propia imagen que se refleja en la fuente, en un juego especular entre imagen real e imagen refleja que emerge a través de intensas refracciones de la luz. De Ovidio a Caravaggio hasta Calderón el mito, entre poesía, pintura y teatro representa la imagen icónica en su máxima entropía. Sin embargo, destacan las afinidades metafóricas entre la pieza calderoniana y el lienzo Eco y Imagen 23. Jan Cossiers, Nariso (1636-1638). 


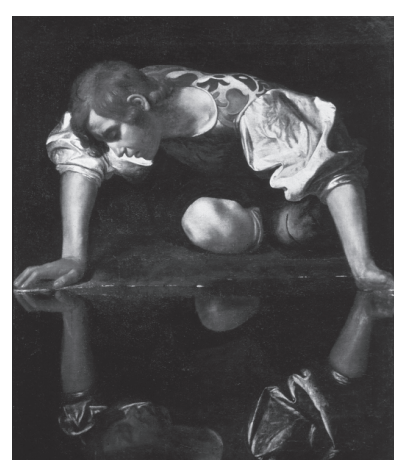

Narciso (1625) de Nicolas Poussin evocadas tanto en el lenguaje poético como en el pictórico. En la pintura Narciso yace muerto en el suelo a causa de su misma pasión imposible y de su cuerpo sin vida van brotando las caducas flores que llevan su mismo nombre. El amorcillo con la antorcha es un Pathosformeln que viene del arte funerario antiguo que, evocando el encendimiento de la pira, junta en la misma imagen el poder del Eros con Imagen 24. Michelangelo Merisi Caravaggio, el ineluctable del Thanatos. Desde el fondo Narciso en la fuente (1599). del tableau, aflorando de las rocas, Eco mira al infeliz Narciso, pero como un fantasma que está para disolverse.

En Calderón la tragedia de los dos jóvenes se representa con efectos escenográficos asombrosos: y es la misma Liríope que con sus palabras nos deja ver la metamorfosis de Eco en aire y de Narciso en su misma flor:

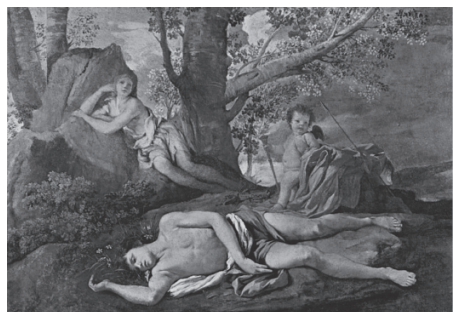

Imagen 25. Nicolas Poussin, Eco y Nariso (1627-1628). Museo del Louvre de París.

Liríope Cumplió el hado su amenaza, valiéndose de los medios que para estorbarlo puse; pues ruina de entrambos fueron una voz y una hermosura, aire y flor entrambos siendo. (p. 1940)

Ni Amor se libra de Amor, representada en 1662, pone en escena, con cierta libertad por parte de Calderón, la fábula de Psique y Cupido narrada por Apuleyo en el Libro XI, de sus Metamorfosis. El asno de oro.

Fundamental es la compleja organización del espacio escénico que se articula a través de la alternancia entre los dos teatros regios - el palacio paterno y el del esposo divino- y los dos loci amoeni contiguos. La escenografia reproduce los efectos maravillosos de los teatros - teatro de mar, de bosque, etc.- los cambi a vista y una isla de encantamientos. En la Jornada Tercera se representa el Palacio de Cupido, de manera inusual, en un «teatro de infierno» que en fin se abre a la apoteosis final. 
Enriquecida por el canto y las músicas, la sucesión de los teatros ofrece a la mirada un desarrollo metonímico que es mero gozo de la visión por sí misma. El desarrollo de los tableaux, reforzado, desde el punto de vista de la visualización, por el preciosismo del verso en un juego de correspondencias, intercambios simétricos, sonoros y conceptuales, agudezas, bisemias y falsos silogismos conceptuosos, se hace cargo de suscitar la deixis de las posturas con fuerte connotación icónica, y de actualizar, gracias al decorado verbal, el admirable movimiento escénico ${ }^{25}$. Por consiguiente podría suponerse que la fête galante, Psyché, de Molière-Lulli, que estrena en Versailles en 1671, tuvo como modelo la «fiesta real» de Calderón.

En la vertiente icónica lo interesante de la didascalia en apertura de la fiesta, es aquel detalle de Selenisa que baila "suelta el cabello» y coronadas de flores que no puede dejar de evocarnos representaciones pictóricas de ninfas como connotación del Eros cósmico, a partir de la Primavera del Botticelli. La misma iconografia dibuja la hermana Astrea al salir con el Coro Segundo; luego con el Coro Tercero aparece Siquis con sus damas bailando adornadas de guirnaldas. Tanto en el tableau pictórico, como en el tableau dramático calderoniano, la representación del triunfo de la belleza de corte construye la metáfora cosmológica: Selenisa, Astrea y Siquis son nombres que ponen en relación las esferas celestes con el soplo vital de la naturaleza y de los hombres, según una visión neo-platonizante.

Mientras se despliegan los tres perfiles atraviesa el espacio teatral el eco de un retornelo que invita a ir al templo de Venus y Amor, para ofrecer adoración al simulacro de Venus. El canto de Siquis «danzante», con el coro en eco, enciende aquel deseo de adoración incitando a "correr con planta veloz [...] a rendir el corazón» a la diosa, la cual «vibra en sus ojos [...] los arcos de la diosa y las flechas del dios». (p. 1944)

Éstas y otras danzas acompañadas por el canto - las bodas de las hermanas que se ven en el fondo de la caverna/Palacio; el triunfo de la apoteosis final- hacen que Ni Amor se libra de Amor pueda considerarse la más cumplida realización teatral de la síntesis entre poesía, artes figurativas, música y danza.

En las fiestas de las más importantes Cortes europeas, gracias a las contribuciones de los maestros coreógrafos - el Domenichino, Belgioioso, Beauchamps y Lulli- la coreografia se hace obra de arte visiva. La constante presencia de bailes y coreografias en las comedias mitológicas es, por lo tanto, una práctica que contribuye a las estrategias

\footnotetext{
${ }^{25}$ Ver Cancelliere, 2013, pp. 21-48.
} 
icónicas que miran a la visualización del texto dramático como síntesis de todas las artes: en una palabra "teatro», a la letra "visión admirable».

La logia de Amore e Psiche de la Farnesina muestra el magnífico ciclo de Raffaello, comienzos del Quinientos, donde rodeadas por los varios episodios de la fábula de Apuleyo, campean en el centro las escenas narrativas de la apenada peroración de Cupido a los dioses del Olimpo en favor de la amada y de las bodas.

También Tiziano pinta a los dos amantes y a Cupido que vela a Siquis durmiente; y según la misma manera Van Dyck en 1638. Sin embargo, es de Giulio Romano - que ya había trabajado a la obra de Raffaello- el grande ciclo en el Palacio Te de Mantua que ilustra to-

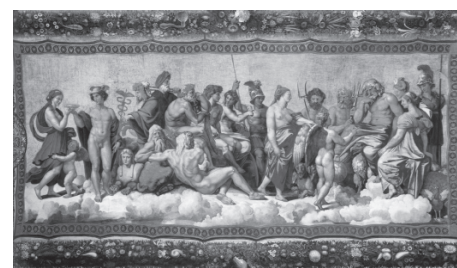

Imagen 26. Raffaello Sanzio, Concilio de los Dioses Logia de Amor y Psique (1517-1518) Villa Farnesina de Roma. dos los episodios fundamentales de la Fábula y llega a fijar las tipologías pictóricas de las postura de los protagonistas, como se ve en el tableau que muestra a Siquis pendiente sobre el joven adormecido para ver su cara, con una antorcha en una mano en la otra un puñal.

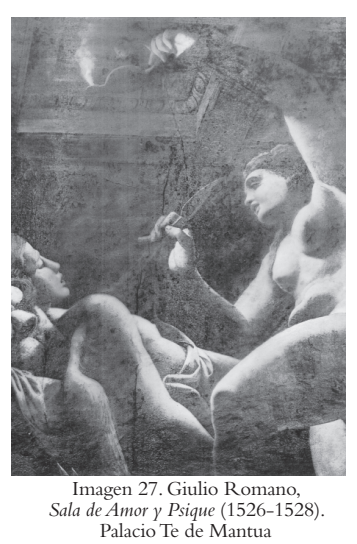

El mismo tableau está presente en el texto poético y constituye el núcleo del drama: el tálamo de los dos amantes, la dulzura del abrazo y la insidia que en él se anida. La ninfa canta una dulce nana para adormecer al dios niño, mientras todos los elementos del universo con su armonía lo inducen al sueño.Y es ahora cuando Siquis pasa a la acción. La construcción del icono llega a su máximo valor de entropía. Con el puñal en una mano y la antorcha en la otra, Siquis se queda suspendida sobre el bello joven durmiente. Pero cuando la luz deja ver al amado en toda su belleza exclama:

Siquis

¿Quién vio más bella pintura?

¿Quién más perfecta escultura?

El que dijo que este es

un monstruo, dijo bien, pues

es un monstruo de hermosura. (p.1979)

El icono, ya gongorino, atraviesa la pintura manierista y barroca, entre los muchos ejemplos hace falta recordar: Venus y Adonis de Veronese; Diana y Endimión de Carracci, etc. 
La escena del banquete nupcial en el fresco de Giulio Romano se desarrolla en un locus amoenus, que mezcla flores, fuentes, las cornucopias con las Náyades, dioses, seres humanos, sátiros etc., una especie de renovada Edad de Oro. En el centro la pareja divina echada en el tálamo nupcial con su hija, la Voluptas. Luego, en el centro del techo, Amor y Siquis están pintados en un vuelo que ahora va desarrollándose a lo largo de un eje vertical en una visión aberrada, hacia el rayo de luz deslumbrante. Sin embargo, es sorprendente el cromatismo de esos

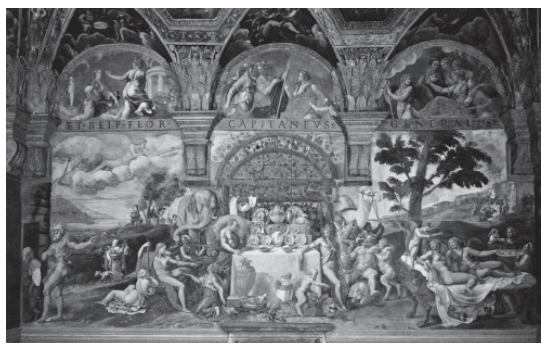

Imagen 28. Giulio Romano, Banquete de los dioses (1526-1528). Palacio Te de Mantua. cielos pintados al óleo con matices de gris, azul-noche, naranja y rojo sombrío que parecen sugerir las profundidades infernales y no de las esferas celestes. La visión aberrada contre-plongée del pintor es inversamente especular a la visión plongée del poeta que a través de las tinieblas llega a una luz sepultada en las entrañas de la tierra.

En fin, en La estatua de Prometeo (1670) vuelve el tema del simulacro. La concepción platonizante del papel activo del doble en las artes deriva de las reflexiones sobre la filosofia del Maestro elaboradas por la Accademia Fiorentina a comienzos del siglo XVI. De hecho Platón en el Timeo había afirmado: "Cualquier cosa, pues, de la que el demiurgo realice la forma y la potencia mirando a lo que se mantiene idéntico a sí mismo y sir-

viéndose de eso como modelo, resulta por Detalle de la sala 29 de Giullio Romano, Psique (1526-1528). necesidad totalmente bella» ${ }^{26}$.

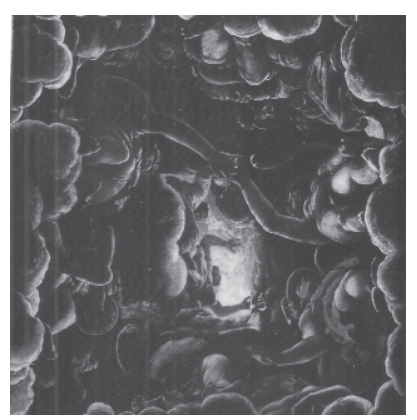

En el ámbito de la tradición figurativa neo-platónica una alegoría de Piero di Cosimo de 1515, Prometeo conforma al hombre, nos muestra al héroe como artífice de estatuas y por consiguiente plasmador de seres vivientes y por eso acogido en cielo gracias a Minerva.

A las mismas fuentes humanísticas y filosóficas remiten tanto la obra pictórica como la poética. En ésta el robo del fuego del carro de Apolo, como se ve también en el lienzo de Jan Cossiers Prometeo que roba el fuego, primera

\footnotetext{
${ }^{26}$ Platón, Timeo, 28 a-b (trad. de la autora).
} 


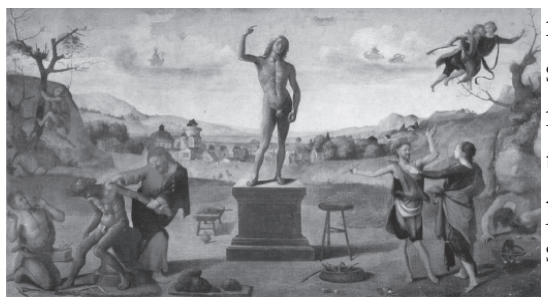

Imagen 30. Piero di Cosimo, Prometeo conforma al hombre (1515). Pinacoteca Antigua de Múnich.

mitad siglo XVII, infunde la vida al simulacro que representa las bellas formas intelectivas de las Artes y de todas las Ciencias -Pandora-: el paso de las obras terrenas a la forma sublime que las trasciende.

En conclusión, las estrategias icónicas de la escritura calderoniana constituyen el patrimonio iconográfico organizado por taxonomías en el contexto de una nueva elaboración diegética que las somete a una especie de torsión de los significados codificados. Se determina, por consecuencia, una función interpretante del elemento iconográfico, por una parte transmitida y por otra original en cuanto idiolecto de autor, cuya valencia taxonómica se hace iconológica.

Hércules que se desespera porque en el acto de salvar a su Deyanira, quisiera, por sus celos, matarla; Ariadna cuyo lamento expresa la profecía de las infaustas bodas de su amado con Fedra; Adonis, aquí no puer sino vir, que, no obstante fascinado por Venus, heroicamente renuncia a ella sacrificando a sí mismo por la necesidad de su empresa; Faetón que desafiando a los cielos desafía su propia imagen que quisiera como la de su padre; Eco desmembrada cuya imagen en vano puede, gracias al canto, aspirar a una totalidad perdida; Prometeo sapiente artífice de simulacros vivientes, etc., son

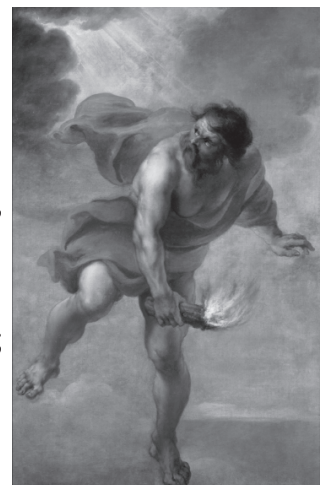

Imagen 31. Jan Cossiers, Prometeo que roba el fuego (1637) Museo del Prado de Madrid. las contaminaciones y las creaciones que iconológicamente evocan imágenes cargadas de plurisignificantes connotaciones gracias al preciocismo de los versos cuya cualidad metafórica siempre nos invita a formular imágenes mentales y dotadas de Pathosformeln textuales: colores, elementos de los reinos minerales y naturales, signos de puntuación, suspiros y admiraciones, metáforas codificadas, etc. acentúan las aficiones patéticas suscitadas a lo largo de la diégesis.

En fin, el admirable corpus mitológico calderoniano adquiere un valor contextual e interpretante con respecto a las Artes figurativas; o sea un valor de patrimonio poético que, entregado a nuestra memoria, nos permite todas las formas de análisis sobre lo visible, puesto que de lo visible recibe iluminación. 


\section{BiBLIOGRAFÍA}

Arellano, Ignacio, "Valores visuales de la palabra en el espacio escénico del Siglo de Oro», Revista Canadiense de Estudios Hispánicos, 19, 3, 1995, pp. 411-442.

Arellano, Ignacio, «El teatro de corte y Calderón», en La singolarità storica e estetica de "La púrpura de la Rosa» di Calderón de la Barca, ed. María Luisa Tobar, Messina, Armando Siciliano Editore, 2000, pp. 31-53.

Arellano, Ignacio, «Espacios dramáticos en el teatro de Calderón», en Calderón: sistema dramático y técnicas escénicas, ed. Felipe B. Pedraza, Rafael González Cañal y Elena E. Marcello, Almagro, Universidad de Castilla-La Mancha, 2001, pp. 77-106.

Aristóteles, Retórica, edición bilingüe, introd. Fausto Montanari, ed. y trad. Mario Donati, Milano, Mondadori, 1996.

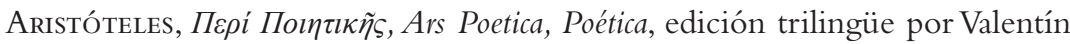
García Yerba, Madrid, Editorial Gredos, 1999.

Becker, Daniéle, «El teatro palaciego y la música en la segunda mitad del siglo viI", en Actas del IX Congreso de la Asociación Internacional de Hispanistas, Berlín / Frankfurt am Main,Vervuert, 1989, pp. 353-363.

Bотто, Ida Maria, Disegni di Bernardo Buontalenti, catalogo e introduzione, Firenze, Olschki, 1968.

Cancelliere, Enrica, «Dell'iconologia calderoniana», en Colloquium Internationale Calderonianum, L'Aquila, Edigrafica Sus Europa, 1981, pp. 5-19.

Cancelliere, Enrica, "Campo dello sguardo e della parola in una commedia di Calderón", en Semiotica della rappresentazione, ed. Renato Tomasino, Palermo, Flaccovio Editore, 1984, pp. 295-303.

Cancelliere, Enrica, "Calderón y el teatro de Corte», Cervantes, 0, 2001, pp. 117-132.

Cancelliere, Enrica, "Pandora: mito e icono para una Fiesta Real», Anuario Calderoniano, Otro Calderón. Homenaje a Maria Teresa Cattaneo, coord. Alessandro Cassol y Juan Manuel Escudero, 3, Madrid / Frankfurt, Iberoamericana /Vervuert, 2010, pp. 67-85.

Cancelliere, Enrica, «Amor y Psique. Hermenéutica de una fábula de las Artes figurativas al teatro de Calderón», Anuario Calderoniano, coord. Alejandra Ulla Lorenzo, vol. extra, 1, Madrid / Frankfurt, Iberoamericana / Vervuert, 2013, pp. 21-48.

Chapman, William C., "Las comedias mitológicas de Calderón», Revista de Literatura, 5, 1954, pp. 35-67.

Curtius, Ernst, «Calderón und die Malerei», Romanische Forschungen, 1936, pp. 89-136.

Didi-Huberman, Georges, Ninfa moderna. Saggio sul panneggio caduto, ed. y trad. Aurelio Pino, Milano, Il Saggiatore, 2004. 
Egido, Aurora (ed.), Calderón de la Barca, Pedro, La fiera, el rayo y la piedra, Madrid, Cátedra, 1989.

LEE, Rensselaer W., Ut pictura poësis. La teoría humanística de la pintura, Madrid, Ensayos / Arte Cátedra, 1982.

Ovidius Naso, Publius, Metamorphoseon Libri XV, ed. Favole D’Ovidio, Torino, Paravia, 1959.

PAnOfsky, Edwin, Studi di Iconologia, Torino Einaudi, 1975.

Platón, Timeo, ed. y trad. Guiseppe Lozza, Milano, Biblioteca Universale Rizzoli, 1994.

Porfirio, Sui simulacri, introd. y comentario Marco Gabriele, trad. Francesco Maltomini, Milano, Adelphi Edizioni, 2012.

Sorolla, Manero P., «El precepto horaciano de la relación "fraterna" entre pintura y poesía y las poéticas italo-españolas durante los siglos XVI, XVII, XviII", Boletín de la Biblioteca Menéndez y Pelayo, LXIV, 1988, Santander, pp. 171-191.

Valbuena Prat, Ángel, «La escenografía de una comedia de Calderón», Archivo Español de Arte y Arqueología, CVI, 1930, pp. 1-16.

Warburg, Aby, La rinascita del paganesimo. Contributi alla storia della cultura, Firenze, La Nuova Italia, 1966.

Warburg, Aby, Mnemosyne. L'Atlante della memoria, Torino, Aragno, 2002. 